\title{
PENGARUH PERBANDINGAN RUMPUT LAUT (Eucheuma cottonii) DAN IKAN LAYANG (Decapterus spp.) PADA PEMBUATAN KERUPUK TERHADAP UJI ORGANOLEPTIK, FISIK DAN KIMIA KERUPUK
}

The Effect of Comparison of Seaweed (Eucheuma cottonii) and Mackerel Scad fish (Decapterus spp.) In Production of crackers to Organoleptic, Physical and Chemistry Analysis

\author{
Karmila Dawista1*, Hermanto2, Suwarjoyowirayatno1 \\ 1Jurusan Teknologi Hasil Perikanan, Fakultas Perikanan dan IImu Kelautan Universitas Halu Oleo, Kendari, \\ Sulawesi Tenggara, Indonesia \\ 2Jurusan IImu dan Teknologi Pangan, Fakultas Pertanian Universitas Halu Oleo, Kendari, Sulawesi Tenggara, \\ Indonesia \\ *Email korespondensi: karmilad9@gmail.com(Telp: +6282188426948) \\ Diterima: 14 Agustus Oktober/ Disetujui 20 September 2019
}

Cara sitasi: Dawista K, Hermanto, Suwarjoyowirayatno. 2019. Pengaruh perbandingan rumput laut (Eucheuma cottonii) dan ika layang (Decapterus spp.) pada pembuatan kerupuk terhadap uji organoleptik, fisik dan kimia kerupuk. Jurnal Fish Protech. 2(2):140147.

\section{ABSTRACT}

The aims of this study are to determine the effect of seaweed (Eucheuma cottonii) and mackerel scad fish (Decapterus spp.) ratio for the organoleptic, physical and chemical test of crackers. This study used a Completely Randomized Design (CRD) which four treatments P1 (FM 20\%: S 5\%: TF 75\%), P2 (FM 15\%: S 10\%: TF 75\%), P3 (FM 10\% : S 15\%: TF 75\%) and P4 (FM 5\%: S 20\%: TF 75\%) with three times replications. Observation data were analyzed using ANOVA (Analysis of Variance) at the level of $95 \%$, if there were significant differences ( $P>0.05$ ) then further testing was carried out by DMRT (Duncan Multiple Range Test) at $95 \%$ significance level. The result showed that seaweed and mackerel scad meat ratio had a significant effect on sensory values (aroma, taste, and crispness). The best results for the sensory test were found in P1 where the taste and aroma value was 7.8 and 7.7 , while the best result for texture, crispness, and appearance are 7.2, 4.3 and 7.3 was found in P4. The chemical test on crackers for protein, water content and crude fibre was $6,97 \%-11,50 \%, 3,80 \%-4,96 \%$ and $1,81-4,44 \%$ respectively. The physical test of the rising volume shows that P4 had the highest value with $92 \%$.

Keywords: Crackers, mackerel scad fish (Decapterus spp.), seaweed (E. cottoni), organoleptic test, chemical test

\begin{abstract}
ABSTRAK
Tujuan penelitian ini adalah untuk mengetahui pengaruh perbandingan rumput laut (Eucheuma cottonii) dan ikan layang (Decapterus spp.) terhadap uji organoleptik, fisik dan kimia kerupuk. Penelitian ini menggunakan Rancangan Acak Lengkap (RAL) yang terdiri dari empat perlakuan yaitu perlakuan P1(DI 20\%: RL 5\%: TT 75\%), P2 (DI 15\%:RL 10\% : TT 75\%), P3(DI 10\% : RL 15\% : TT 75\%) dan P4(DI 5\% : RL 20\% : TT 75\%) dan ulangan sebanyak tiga kali. Data hasil pengamatan dianalisa menggunakan ANOVA (Analysis of Variance) pada taraf $95 \%$, apabila terdapat beda nyata $(\mathrm{P}>0,05)$ maka dilakukan uji lanjut dengan uji DMRT (Duncan Multiple Range Test) pada taraf nyata 95\%. Hasil penelitian yang diperoleh menunjukkan pengaruh nyata terhadap nilai sensori yang meliputi aroma, rasa, dan kerenyahan. Hasil terbaik untuk penilaian sensori terdapat pada perlakuan P1 dimana memiliki nilai rasa 7,8 dan aroma 7,7 sedangkan perlakuan terbaik untuk tekstur 7,2 dan kerenyahan 4,3 terdapat pada perlakuan P4 dan kenampakkan 7,3,. Hasil penelitian menunjukkan kadar protein 6,97\%-11,50 6,97\%, kadar air antara 3,80\%-4,96\% dan kadar serat kasar 1,81\%4,44. Hasil uji fisik volume pengembangan menunjukkan nilai terbaik yaitu perlakuan P4 dengan nilai volume pengembangan $92 \%$.
\end{abstract}

Kata kunci: Eucheuma cottonii, Ikan layang (Decapterus spp), Kerupuk, uji organoleptik, uji kimia 


\section{PENDAHULUAN}

Kerupuk merupakan salah satu makanan ringan yang dikonsumsi sebagai makanan selingan atau sebagai makanan pelengkap makanan reguler. Umumnya kerupuk merupakan sumber karbohidrat sehingga diperlukan peningkatan nilai gizinya terutama kandungan protein dan serat. Selama ini kerupuk dimanfaatkan sebagai cemilan yang biasanya terbuat dari ikan, udang, atau tanpa campuran apapun. Oleh karena itu, perlu dilakukan variasi rasa dan peningkatan nilai gizi, salah satunya kerupuk yang dibuat dari campuran rumput laut (E. cottonii) dan ikan layang (Decapterus spp.).

Ikan layang (Decapterus spp.) merupakan salah satu ikan yang dikenal sebagai mackerel fish yang termasuk ikan yang mudah didapatkan dan banyak dikonsumsi masyarakat karena memiliki harga yang relatif murah, rasa yang cukup enak serta ikan layang memiliki kandungan gizi yang cukup tinggi. Umumnya, komposisi kimia daging ikan terdiri dari air 66-84\%; protein 15-24\%; lemak 0,122\%; karbohidrat 1-3\% dan bahan anorganik 0,8-2\% (Suzuki, 1981). Menurut Irianto dan Soesilo (2007), ikan layang memiliki kandungan gizi yang tinggi, protein sebesar $22,0 \%$, kadar lemak rendah $1,7 \%$ sehingga lebih menguntungkan bagi kesehatan. Penggunaan ikan layang dianggap sangat menguntungkan, dilihat dari kandungan protein yang cukup tinggi untuk meningkatkan pemanfaatan dan nilai tambah pada suatu olahan produk, sehingga penggunaan ikan layang cocok untuk dijadikan bahan fortifikasi pada pembuatan produk perikanan.

Produk perikanan merupakan salah satu bahan makanan yang bernilai gizi tinggi, yaitu sebagai sumber protein hewani yang dibutuhkan dalam makanan sehari-hari, yang tidak selalu dikonsumsi dalam keadaan segar tetapi sebagian diolah terlebih dahulu menjadi berbagai bentuk dan jenis lain (Aryani et al., 2016). Pengolahan bertujuan untuk penganekaragaman macam makanan (diversifikasi). Salah satu produk olahan makanan adalah kerupuk. Kandungan gizi kerupuk paling dominan adalah karbohidrat, sedangkan kandungan lain dari kerupuk umumnya relatif rendah (Ratnawati, 2013). Konsumsi kerupuk tidak memberikan asupan gizi yang signifikan karena kandungan kerupuk lebih banyak mengandung tepung dibanding dengan porsi bahan lainnya. Perlu adanya fortifikasi seperti ikan dan rumput laut untuk menambah nilai gizi kerupuk.

Produksi rumput laut di Indonesia mencapai 3,082 juta ton pada tahun 2010. Salah satu jenis rumput laut yang dapat dimanfaatkan adalah $E$. cottonii. Rumput laut jenis ini digunakan dalam pembuatan berbagai macam produk makanan dan minuman karena memiliki sifat yang tidak mengurangi kelezatan makanan (Ariyani dan Ayustaningwarno, 2013). Rumput laut merupakan bahan yang potensial sebagai sumber serat pangan dengan beberapa keunggulan dibandingkan dengan bahan pangan asal tumbuhan darat. Rumput laut E. cottonii dikenal sebagai sumber serat. Serat merupakan komponen penting dalam bahan pangan, terutama dalam menjaga kesehatan dan keseimbangan fungsi sistem pencernaan. Serat pangan dikenal memiliki nilai kesehatan yang penting, terutama dalam mengurangi kolesterol dalam darah, memperbaiki penyerapan glukosa bagi penderita diabetes, mencegah penyakit kanker usus, dan membantu menurunkan berat badan (Dwiyitno, 2011). Berdasarkan kandungan gizi yang baik pada rumput laut, sehingga dapat dimanfaatkan dengan menambahkan ikan layang pada pembuatan kerupuk.

\section{METODE PENELITIAN}

\section{Alat dan Bahan}

Alat yang digunakan dalam penelitian ini yaitu cetakan (stainless steel), blender (Miyako), thermometer (Torbalscale), tabung reaksi, cawan porselin, vortex (Thermo Maxi), timbangan analitik (Torbalscale), hot-plate, desikator, erlenmeyer, tanur (Furnace D550) dan alat destilasi.

Bahan yang digunakan dalam penelitian ini adalah rumput laut (E. cottonii), ikan layang (Decapterus spp.), tepung tapioka, telur, garam, gula dan bawang putih. Bahan kimia untuk analisis kimia adalah aquades, alkohol $80 \%, \mathrm{NaOH}, \mathrm{H}_{2} \mathrm{SO}_{4}$, kertas saring, heksan, dan larutan standar protein. 


\section{Rancangan Penelitian}

Rancangan percobaan yang digunakan dalam penelitian ini adalah Rancangan Acak Lengkap (RAL) satu faktor yang terdiri dari empat perlakuan. Faktor yang diamati adalah perbandingan antara tepung tapioka, ikan layang (Decapterus spp.) dan bubur rumput laut (E. cottonii) terhadap karakteristik kerupuk yaitu P1 (75\% tepung tapioka: 20\% ikan layang: 5\% rumput laut), P2 (75\% tepung tapioka: $15 \%$ ikan layang: $10 \%$ rumput laut), P3 (75\% tepung tapioka: 10\% ikan layang: $15 \%$ rumput laut), P4 (75\% tepung tapioka: $5 \%$ ikan layang:20\% rumput laut).

\section{Pembuatan Kerupuk \\ Penyiapan Bahan Baku}

Rumput laut kering jenis $E$. cottonii yang digunakan diperoleh dari CV. Sinar Laut, Kelurahan Lapulu, Kecamatan Abeli, Kota Kendari, Sulawesi Tenggara dalam bentuk kering dan Ikan Layang (Decapterus spp.) berasal dari Tempat Pelelangan Ikan Kendari, Sulawesi Tenggara dalam bentuk segar.

\section{Pembuatan Bubur Rumput Laut}

Pembersihan dan pencucian rumput laut dengan air tawar dilakukan untuk menghilangkan batu, kerikil, lumpur, kerang dan benda-benda asing lainnya. Perendaman Rumput laut (Eucheuma cottonii) kering dengan menggunakan air cucian beras putih dengan perbandingan 1:3 (100 gr rumput laut direndam dengan $300 \mathrm{ml}$ air cucian beras) selama satu hari. Rumput laut yang telah direndam ditambahkan air dengan perbandingan 1:1, lalu dimasak dengan suhu $100^{\circ} \mathrm{C}$ selama 5 menit. Rumput laut diblender hingga halus (Hatta, 2017).

\section{Pembuatan kerupuk}

Penyiapan bahan baku yaitu tepung tapioka, rumput laut (E. cottonii.) dan ikan layang (Decapterus spp.) dan bumbu-bumbu (bawang putih $7 \mathrm{~g}$, telur $12 \mathrm{~g}$, garam $5 \mathrm{~g}$, gula $10 \mathrm{~g}$ dan air $35 \mathrm{~mL}$ ), lalu dimasukkan ke dalam wadah dan diaduk hingga homogen. Pencetakan dengan menggunakan selongsong stainless steel dengan panjang $15 \mathrm{~cm}$ dan diameter 4 $\mathrm{cm}$, kemudian dikukus selama 2 jam dan selanjutnya dilakukan pendinginan selama 24 jam dengan suhu ruang $27^{\circ} \mathrm{C}$. Pengirisan dengan ketebalan $3 \mathrm{~mm}$ dan dikeringkan dengan sinar matahari selama 3 hari. Penggorengan dengan suhu $125^{\circ} \mathrm{C}$ selama 5 detik dengan jumlah kerupuk sebanyak 8 kerupuk (Rosiana et al., 2015).

\section{Parameter uji}

Uji Sensori (SNI. 01-2346. 2006), Uji Fisik (Volume Pengembangan Zulviani, 2000). Analisis uji kimia meliputi kadar air (AOAC, 1995), kadar protein (AOAC,1995) dan kadar serat kasar (AOAC,1995).

\section{Analisis Data}

Analisis data yang digunakan dalam penelitian ini adalah dengan menggunakan sidik ragam Analysis of Varian (ANOVA) dan jika hasil analisa terdapat perbedaan nyata, maka akan dilanjutkan dengan uji lanjut Duncan's Multiple Range Test (DMRT) pada taraf kepercayaan $95 \%(\alpha=0,05)$.

\section{HASIL DAN PEMBAHASAN}

\section{Uji sensori}

Tabel 1. Hasil analisis uji sensori

\begin{tabular}{cccccc}
\hline & \multicolumn{5}{c}{ Uji sensori } \\
\cline { 2 - 6 } Perlakuan & Kenampakkan & Aroma & Rasa & Tekstur & Kerenyahan \\
\hline P1 & $6,7 \pm 0,2$ & $7,7 \mathrm{~d} \pm 0,1$ & $7,8 \mathrm{~cd} \pm 0,1$ & $6,7 \pm 0,4$ & $3,7 \mathrm{a} \pm 0,1$ \\
P2 & $6,8 \pm 0,4$ & $7,6 \mathrm{bc} \pm 0,1$ & $7,7 \mathrm{c} \pm 01$ & $6,9 \pm 0,6$ & $3,9 \mathrm{ab} \pm 0,3$ \\
P3 & $7,0 \pm 0,2$ & $7,5 \mathrm{ab} \pm 0,2$ & $7,4 \mathrm{~b} \pm 0,3$ & $7,1 \pm 0,5$ & $4,1 \mathrm{bc} \pm 0,2$ \\
P4 & $7,3 \pm 0,3$ & $7,4 \mathrm{a} \pm 0,1$ & $7,3 \mathrm{a} \pm 0,2$ & $7,2 \pm 0,1$ & $4,3 \mathrm{~cd} \pm 0,3$
\end{tabular}

Keterangan: Angka yang diikuti notasi huruf yang berbeda pada kolom yang sama menunjukkan berbeda nyata $(P<0,05)$ 


\section{Kenampakan}

Hasil uji sensorik kenampakkan pada kerupuk didapatkan nilai rerata tertinggi terletak pada perlakuan P4 sebesar 7,3 dan nilai rerata terendah terletak pada perlakuan P1 sebesar 6,7. Hasil uji sensorik menunjukkan bahwa perbandingan ikan layang dan rumput laut pada pembuatan kerupuk tidak mempengaruhi nilai organoleptik pada kenampakannya. Secara garis besar kenampakan pada kerupuk ikan menunjukkan hasil yaitu rapi, bersih, kurang homogen, ketebalan kurang rata, warna agak kecoklatan. Warna kecoklatan pada kerupuk disebabkan oleh adanya reaksi browning non enzimatis (reaksi maillard) setelah digoreng. Reaksi maillard terjadi karena adanya asam amino lisin dan glukosa yang bereaksi pada suhu tinggi sehingga menghasilkan senyawa melanoidin yang membuat bahan berwarna coklat (Winarno, 1992). Menurut Abubakar (2009) asam amino lisin berasal dari pemecahan struktur heliks dan ikatan peptida kolagen akibat pemanasan secara bertahap.

\section{Aroma}

Pengujian sensorik pada kerupuk menunjukkan pada aroma kerupuk nilai rerata tertinggi terletak pada perlakuan P1 sebesar 7,7 dan nilai terendah terletak pada perlakuan $\mathrm{P} 4$ sebesar 7,4, diketahui bahwa ratarata nilai aroma kerupuk pada kerupuk terhadap perlakuan yang diberikan dapat menurunkan aroma kerupuk pada kerupuk, Hasil nilai uji sensorik aroma pada penelitian ini sesuai dengan nilai aroma fortifikasi tepung tulang julung-julung sebagai sumber kalsium terhadap tingkat kesukaan kerupuk dari hasil penelitian Deborah et al. (2016) yaitu 7,7. Hasil tersebut menunjukkan bahwa semakin banyak ikan layang yang ditambahkan, semakin meningkatkan atribut aroma kerupuk walaupun rumput laut juga memberikan pengaruh aroma namun tidak signifikan. Aroma kerupuk yang dihasilkan secara umum masih kuat spesifik ikan dan berbanding lurus dengan atribut rasa. Menurut Setiawan et al. (2103), bertambahnya jumlah ikan yang mengandung protein dan lemak sebagai aroma ikan yang ada pada adonan membuat aroma kerupuk menjadi semakin tajam.

\section{Rasa}

Pengujian sensorik pada kerupuk terhadap rasa kerupuk menujukkan nilai rerata tertinggi terletak pada perlakuan P1 sebesar 7,8 dan nilai terendah terletak pada perlakuan P4 sebesar 7,3. Kerupuk pada perlakuan P1 memiliki rasa khas ikan yang lebih kuat dibandingkan kerupuk lainnya. Hal ini berkaitan dengan karakter ikan layang sebagai bahan baku. Kerupuk pada perlakuan P1 memiliki rasa khas ikan yang lebih kuat dibandingkan kerupuk lainnya. Hal ini disebabkan karna banyaknya jumlah kosentrasi ikan layang pada perlakuan P1 dibandingkan dengan perlakuan lainnya. Menurut pendapat Neiva et al. (2011) menyatakan bahwa seiring bertambahnya konsentrasi ikan maka rasa ikan pada produk lebih terasa. Hasil penelitian ini serupa dengan penelitian Rizky et al. (2017) tentang perbandingan penambahan ikan teri (Stolephorus sp.) dan rumput laut caulerpa racemose, menunjukkan hasil penelitian uji organoleptik pada penambahan ikan teri $15 \%$ dan bubur rumput laut $10 \%$ dengan nilai rerata sebesar 5,3 $(5,597<\mu<6,437)$ atau disukai panelis. Hasil ini menunjukkan bahwa perbandingan ikan layang dan rumput laut dapat menambah atribut rasa kerupuk sehingga dapat diterima, dan cukup disukai oleh konsumen.

\section{Tekstur}

Hasil uji sensorik menunjukkan bahwa nilai rerata tertinggi terdapat pada perlakuan $\mathrm{P} 4$ yaitu 7,2 dan rerata terendah terdapat pada perlakuan $\mathrm{P} 1$ yaitu 6,7. Kerupuk pada perlakuan P1 memiliki penilaian terendah karena memiliki tekstur yang keras. Hal tersebut disebabkan oleh ikan layang yang memiliki kadar protein cukup tinggi, sedangkan kerupuk pada perlakuan P4 cenderung disukai karena kerupuk tersebut memiliki tekstur yang renyah. Bahan baku yang mengandung protein tinggi membuat pengeluaran air pada kerupuk menjadi sulit karena rongga udara yang terbentuk pada saat penggorengan semakin kecil. Menurut Rikah (2013) menyatakan bahwa pembentukan rongga udara yang semakin kecil membuat kerupuk kurang mengembang. Hal tersebut 
disebabkan oleh gugus hidrofil pada protein lebih banyak dibandingkan pati. Pengembangan kerupuk yang kurang sempurna menyebabkan tekstur kerupuk menjadi keras.

\section{Kerenyahan}

Kerenyahan selalu berbanding lurus dengan tekstur. Hasil uji organoleptik menunjukkan bahwa rerata nilai kerenyahan pada kerupuk dengan perbandingan ikan layang dan rumput laut terhadap perlakuan yang diberikan dapat meningkatkan kerenyahan pada kerupuk. Kerupuk pada perlakuan P4 memiliki nilai rerata tertinggi sebesar 4,3, sedangkan kerupuk pada perlakuan P1 memiliki nilai rerata terendah yaitu 3,7. Hal tersebut disebabkan karna banyaknya jumlah kosentrasi ikan pada perlakuan $\mathrm{P} 1$ sehingga memiliki protein yang cukup tinggi dibandingkan kerupuk lainnya. Menurut Istanti (2005) menyatakan kandungan protein yang tinggi dapat menyebabkan kantong-kantong udara kerupuk yang dihasilkan semakin kecil karena padatnya kantong-kantong udara tersebut terisi oleh bahan lain yaitu daging ikan yang banyak mengandung protein sehingga dapat menyebabkan daya kembang semakin kecil yang akhirnya dapat menyebabkan kerenyahan semakin menurun.

\section{Uji Fisik}

Tabel 2. Hasil analisis daya kembang

\begin{tabular}{cc}
\hline Perlakuan & Daya Kembang $(\%) \pm$ SD \\
\hline P1 & $54 \mathrm{a} \pm 7,0$ \\
P2 & $54 \mathrm{ab} \pm 7,0$ \\
P3 & $84 \mathrm{bc} \pm 7,5$ \\
P4 & $92 \mathrm{~cd} \pm 8,0$ \\
\hline
\end{tabular}

Keterangan: Angka yang didampingi huruf berbeda pada kolom yang sama menunjukkan berbeda nyata $(P<0,05)$.

\section{Daya Kembang}

Hasil penelitian menunjukkan bahwa kerupuk pada perlakuan $\mathrm{P} 4$ memiliki nilai rerata tertinggi yaitu 92\% dan kerupuk pada perlakuan P1 memiliki nilai rerata terendah sebesar $54 \%$. Hasil ini menunjukkan semakin besar kandungan ikan yang ditambahkan dalam kerupuk menyebabkan daya kembang kerupuk menurun. Penelitian ini menghasilkan data yang tidak jauh berbeda dengan penelitian Huda et al. (2009) tentang penambahan daging ikan dori pada pembuatan kerupuk ikan yaitu sebesar 37.18\%$107.69 \%$. Jika dibandingkan dengan daya kembang kerupuk komersial pada penelitian Huda et al. (2010) menyebutkan bahwa daya kembang kerupuk pada perlakuan sesuai dengan daya kembang kerupuk komersial. Daya kembang kerupuk komersial berada diantara 38\%-145\%. Menurut Kusumaningrum (2009) menyatakan bahwa perbedaan daya kembang menujukan bahwa semakin banyak kandungan amilopektin dalam kerupuk ikan maka daya kembangnya akan semakin besar. Hal ini karena bangunan amilopektin kurang kompak dan kurang menahan pengembangan volume massa sebelum penggorengan. Kandungan amilopektin berasal dari tepung tapioka, oleh karena itu, semakin besar kandungan tepung tapioka dalam kerupuk ikan menyebabkan daya kembang yang semakin besar.

\section{Uji Kimia}

Tabel 3. Hasil Analisis kandungan kimia

\begin{tabular}{cccc}
\hline & \multicolumn{3}{c}{ Uji Kimia } \\
\cline { 2 - 4 } Perlakuan & Kadar air (\%) & Kadar protein (\%) & Kadar serat kasar (\%) \\
\hline P1 & $4,96 \mathrm{~d} \pm 0,3$ & $11,50 \mathrm{a} \pm 2,1$ & $1,81 \mathrm{a} \pm 0,7$ \\
P2 & $4,57 \mathrm{c} \pm 0,4$ & $9,46 \mathrm{ab} \pm 0,4$ & $3,18 \mathrm{~b} \pm 0,9$ \\
P3 & $4,02 \mathrm{ab} \pm 0,7$ & $8,78 \mathrm{bc} \pm 0,2$ & $3,82 \mathrm{bc} \pm 0,3$ \\
P4 & $3,80 \mathrm{a} \pm 0,6$ & $6,97 \mathrm{~cd} \pm 0,2$ & $4,44 \mathrm{~cd} \pm 0,2$ \\
\hline
\end{tabular}

Keterangan: Angka yang didampingi huruf berbeda pada kolom yang sama menunjukkan berbeda nyata $(P<0,05)$. 


\section{Kadar Air}

Hasil uji kadar air menunjukkan bahwa perbandingan ikan dan rumput laut berpengaruh terhadap kadar air kerupuk, nilai rerata tertinggi terdapat pada perlakuan P1 yaitu 4,96 dan terendah terdapat pada perlakuanan P4 yaitu 3,80. Hasil penelitian ini sesuai dengan standar SNI 01- 27132009 tentang kerupuk ikan dengan kadar air maksimal $12 \%$. Hal ini disebabkan karena kerupuk pada perlakuan P1 hingga perlakuan P4 mengandung protein dan serat lebih tinggi yang berasal dari ikan dan rumput laut yang mempengaruhi jumlah kadar air. Menurut Rizky et al. (2017) menyatakan bahwa jenis protein yang ada pada ikan dan rumput laut mampu mengikat kadar air dalam kerupuk sehingga kadar airnya rendah. Menurut Mulyana et al. (2014), perbedaan kadar air dipengaruhi oleh kadar protein pada kerupuk.

\section{Kadar Protein}

Hasil nilai retata kadar protein pada kerupuk dengan perbandingan ikan layang dan rumput laut menunjukkan nilai tertinggi terdapat pada perlakuan P1 yaitu 11,50 dan terendah terdapat pada perlakuan P4 yaitu 6,97. Berdasarkan SNI (2009), kadar protein pada kerupuk minimum $6 \%$. Kadar protein terendah kerupuk hasil penelitian ini masih memenuhi standar yaitu $6,97 \%$. Kadar protein yang rendah menunjukkan kandungan sumber protein yang sedikit dalam formulasi yang digunakan dalam pembuatan kerupuk (Huda et al. 2010). Kandungan protein dalam penelitian ini lebih besar jika dibandingkan dengan kadar protein kerupuk komersial pada penelitian Huda et.al. (2010) kadar protein kerupuk komersial berada dalam kisaran $5,53 \%$ sampai $16.17 \%$.

\section{Kadar Serat Kasar}

Hasil nilai retata kadar serat kasar pada kerupuk dengan perbandingan ikan layang dan rumput laut menunjukkan nilai tertinggi terdapat pada perlakuan P4 yaitu 4,44 dan terendah terdapat pada perlakuan P1 yaitu 1,81 . Hasil pengujian menunjukkan bahwa rerata nilai kadar serat kasar kerupuk dengan perbandingan ikan layang dan rumput laut terhadap perlakuan yang diberikan dapat meningkatkan kadar serat kasar pada kerupuk. Hal ini seiring dengan peningkatan perbandingan bubur rumput laut pada formulasi. Hal tersebut diduga karena bubur rumput laut $E$. cottoni memiliki kandungan serat kasar yang lebih tinggi dibandingkan ikan layang dan tepung tapioka. Hal tersebut didukung oleh penelitian Rizky et al. (2017), hasil uji kadar serat kasar pada kerupuk ikan menunjukkan bahwa penambahan ikan teri dan rumput laut berpengaruh terhadap kadar serat kasar kerupuk ikan. Rata-rata meningkat $\pm 0,91 \%$ pada $\mathrm{F} 1$ (20\% ikan teri: 5\%rumput laut) sampai F4 (5\% ikan teri: $20 \%$ rumput laut).

\section{PENUTUP}

\section{Kesimpulan}

Kesimpulan dari hasil penelitian ini yaitu:

1. Perlakuan perbandingan rumput laut dan ikan layang yang berbeda pada kerupuk terhadap parameter uji sensorik yang diamati berpengaruh nyata terhadap aroma, rasa dan kerenyahan dan tidak berpengaruh nyata terhadap kenampakkan dan tekstur.

2. Perbandingan ikan layang dan rumput laut pada kerupuk terhadap parameter fisik (daya kembang kerupuk) berpengaruh sangat nyata dengan nilai tertinggi terletak pada perlakuan P4 sebesar $92 \%$.

3. Hasil uji kimia kerupuk dengan perbandingan ikan layang dan rumput laut berpengaruh nyata terhadap kadar air dengan hasil kadar air tertinggi terdapat pada perlakuan P1 sebesar 4, 96\% dan berpengaruh sangat nyata terhadap kadar protein dengan nilai tertinggi terdapat pada perlakuan P1 sebesar $11,50 \%$ dan kadar serat tertinggi terdapat pada perlakuan $\mathrm{P} 4$ sebesar $4,44 \%$.

\section{DAFTAR PUSTAKA}

Abubakar Sidik Katili. Struktur dan Fungsi Kolagen. Jurnal Pelangi IImu Vol.2 No.5. 2009. HIm 21 23.

AOAC. 1995. Official Methods of Analysis. Washington: Association of Official Analytical Chemists. 
Ariyani, M. dan Ayustaningwarno, F. (2013) "Pengaruh Penambahan Tepung Duri Ikan Lele Dumbo (Clarias Gariepinus) Dan Bubur Rumput Laut (Eucheuma Cottonii) Terhadap Kadar Kalsium, Kadar Serat Kasar Dan Kesukaan Kerupuk," Journal of Nutrition College, 2(1):223-231.

Badan Standarisasi Nasional. 2006. Cara Uji Organoleptik Pada Produk Perikanan. SNI,012346.2006.

Badan Standarisasi Nasional. 2009. Kerupuk Udang. SNI 01-2714-2009.

Deborah, Tabita., Afrianto., Eddy.,Pratama.,R.I. 2016. Fortifikasi Tepung Tulang Julung-Julung Sebagai Sumber Kalsium Terhadap Tingkat Kesukaan. Jurnal Perikanan Kelautan Vol. VII No. 1 /Juni 2016 (48-53).

Dwiyitno, 2011. Rumput Laut Sebagai Serat Pangan Potensial. Squalen. Balai Besar Riset Pengolahan Produk dan Bioteknologi Kelautan dan Perikanan. Vol.

Hatta, Rachmi. 2017. 2017.Studi Pembuatan Dodol dari Rumput Laut (Eucheuma cottonii)dengan penambahan kacang hijau (Phaseolus eureus). [Skripsi]. Makassar:Fakultas Pertanian, Universitas Hasanuddin.

Huda, N., A.L. Leng., C.X. Yee., dan Herpandi. 2010. Chemical Composition, Colour and Linear Expansion Properties Of Malaysian Commercial Fish Cracker (Keropok). Asian Journal Food Agro-Industry, 3(5):473-482.

Huda, N., A.L. Leng., C.X. Yee., dan Herpandi. 2010. Chemical Composition, Colour and Linear Expansion Properties Of Malaysian Commercial Fish Cracker (Keropok). Asian Journal Food Agro-Industry, 3(5):473-482.

Huda, N., I. Boni., dan I. Noryati. 2009. The Effect Of Different Ratios Of Dory Fish To Tapioca Flour On The Linear Expansion, Oil Absorption, Colour And Hardness Of Fish Crackers. International Food Research Journal 16: 159165.

Irianto E, Soesilo I. 2007. Dukungan Teknologi Penyediaan Produk Perikanan. Jakarta: Badan Riset Perikanan dan Kelautan.

Istanti, I. 2005. Pengaruh Lama Penyimpanan Terhadap Karakteristik Kerupuk Ikan Sapusapu. Skripsi. Fakultas Perikanan dan IImu Kelautan, IPB. Bogor.

Jose M Estevez, Marina Ciancia, Alberto S. Cerezo. The System of Low-Molecular-Weight
Carrageenans and Agaroids from The RoomTemperature-Extracted Faction of Kappaphycus alvarezii. Carbohydrate Research. 325 (2000) 287-299

Kusumaningrum, I. 2009. Analisa Faktor Daya Kembang dan Daya Serap Kerupuk Rumput Laut pada Variasi Proporsi Rumput Laut (Eucheuma cottonii). Jurnal ISSN 1858-2419 Vol. 4, No. 2.

Matanjun, Patricia., Mohamed, Suhaila., Mustapha, Noordin., Muhammad, Kharidah. Nutrient content of tropical edible seaweeds, Eucheuma cottonii, Caulerpa lentillifera and Sargassum polycystum. J Appl Phycol (2009) 21:75-80.

Mulyana., W.H. Susanto., dan I. Purwantiningrum. 2014. Pengaruh Proporsi (Tepung Tempe Semangit: Tepung Tapioka) dan Penambahan Air Terhadap Karakteristik Kerupuk Tempe Semangit. Jurnal Pangan an Agroindustri, 2(4): 113-120.

Neiva, C.R.P., T.M. Machado., R.Y. Tomita., E.F. Furlan., M.J.L. Neto., dan D.H.M. Bastos. 2011. Fish Crackers Development From Minced Fish And Starch: An Innovative Approach To A Traditional Product.

Pratiwi, Fitriani. 2013. Pemanfaatan Tepung Daging Ikan Layang Untuk Pembuatan Stick IKan [Skripsi]. Semarang. Fakultas Teknik, Universitas Negeri Semarang.

Rikah Tababaka. Pemanfaatan Tepung Tulang Ikan Patin (Pangasius sp) sebagai Bahan Tambahan Kerupuk [Skripsi]. Institut Pertanian Bogor. 2004.

Rizky, Dinda., Sumardianto., Wijayanti Ima. 2017. Perbandingan Penambahan Ikan Teri (Stolephorus sp.) dan Rumput Laut Caulerpa racemosa Terhadap Kadar Kalsium, Serat Kasar, dan Kesukaan Kerupuk Ikan. Vol. 6 No. 1 Th. 2017.

Rosiani, N., Basito dan Widowati, E. (2015) "Kajian Karakteristik Sensoris Fisik Dan Kimia Kerupuk Fortifikasi Daging Lidah Buaya (Aloe Vera) Dengan Metode Pemanggangan Menggunakan Microwave," Jurnal Teknologi Hasil Pertanian, 8(2).

Setiawan, M.P.G., H. Rusmarilin., dan S. Ginting. 2013. Studi Pengaruh Zat Pengembang dan Penambahan Ikan Pada Pembuatan Kerupuk Ikan Ubi Jalar.Jurnal Rekayasa Pangan dan Pertanian, 1(2): 1-11. 
Suzuki, T. 1981. Fiss and Krill Protein. Procesing Technology Applied Science Publisher. London.

Winarno, F. G. 2004. Kimia Pangan dan Gizi. PT Gramedia Pustaka Utama. Jakarta. $235 \mathrm{hlm}$. 1992. Kimia Pangan dan Gizi. Jakarta: PT Gramedia PustakaUtama.

Zulfahmi AN, Swastawati F, Romadhon. 2014. Pemanfaatan daging ikan tenggiri
(Scomberomorus commersoni) dengan konsentrasi yang berbeda pada pembuatan kerupuk ikan. Jurnal Pengolahan dan Bioteknologi Hasil Perikanan 3(4):133-139.

Zulviani, R. 2002. Pengaruh Berbagai Tingkat Penggorengan Terhadap Pola pengembangan Kerupuk sagu Goreng [Skripsi]. Bogor: Jurusan Teknologi Pangan Dan Gizi, Industri Pertanian Bogor. 